\title{
Tehnički i stručni termini u spisu o rimskim akveduktima
}

\author{
Izvorni znanstveni rad \\ Original scientific paper
}

UDK 811.131.1'374 Frontin, S. I.

\begin{abstract}
Tehnički su se i stručni termini u Frontinovu spisu De aquaeductu urbis Romae dosad obrađivali u okviru takozvanih specijalnih, odnosno tehničkih registara, i to na način da su se pojedini radovi doticali pojedinih posebnosti stručnog leksika tog spisa. Ovaj rad obuhvaća sve dosad istraživane njegove pojedine posebnosti, kao i one koje dosad nisu uočene ili objavljene te se nastoji dati cjelovita slika tehničkog i stručnog leksika monumentalnog spisa De aquaeductu urbis Romae, koja u ovom slučaju obuhvaća terminologiju vezanu za: gradnju akvedukta, njegove dijelove i kapacitete, cijevi, gravitacijske učinke, distribuciju i protok vode; zatim hapakse, specifične termine na -arius, -orius i vrlo zanimljive probleme oko značenja riječi castra-castellum te sinonimije kod naziva za lučne konstrukcije. Takva analiza pridonosi boljem poznavanju klasičnog latinskog tehničkog vokabulara i olakšava situaciju pri njegovim mogućim poredbenim istraživanjima. U radu se ističe vrijednost hapaksa i načini njihove tvorbe te se, posve razumljivo, zamjećuje određena veza s vulgarnim latinitetom.
\end{abstract}

Ključne riječi: Frontin, De aquaeductu urbis Romae, tehnički leksik, terminologija

\section{Uvod}

ako je Sekst Julije Frontin bio jedan od najistaknutijih rimskih građana i dužnosnika u posljednjoj četvrtini 1. st. po. Kr., ipak se ne radi o općepoznatom autoru prvoga reda. Stoga će se u ovom uvodu prvo dati kratak pregled njegova života i djela te uputiti na literaturu koja se time iscrpnije bavi.

Njegovo su podrijetlo i rana karijera gotovo nepoznati. Rođen je oko 35., a umro oko 103. godine. Bio je gradski pretor u Rimu 70. godine, triput konzul: 73., 98. i 100. godine te namjesnik u Britaniji 73./74.-77./78.. Bio je prokonzul u Maloj Aziji 84./85. godine, a 97. ga je Nerva postavio na dužnost upravitelja rimskog vodoopskrbnog sustava. Bio je također član kolegija augura i dobar poznavatelj prava. Od njegove pisane ostavštine danas imamo očuvano djelo Strategemata (praktični primjeri vojne tematike u vidu poučnih izvadaka), fragmente o zemljomjerstvu te, kako ga sam Frontin naziva, komentar De aquaeductu urbis Romae (o rimskim akveduktima). Spis De re militari (opća vojna tematika) nije sačuvan. Detalji o njegovom rođenju i smrti nisu poznati, no ostala je u jednom Plinijevu pismu (Plin., epist. 9, 19) zabilježena njegova želja, kojom je zabranio da mu se podigne nadgrobni spomenik, poručivši da je to nepotreban trošak, jer se čovjeka pamti po djelima koja je 
iza sebe ostavio. Preporučena i sasvim zadovoljavajuća literatura za iscrpnije informacije o životu i djelu Frontina jesu poglavlja u recentnim izdanjima (Rodgers 2004; Del Chicca 2004), kao i M. Peachin, Frontinus and the curae of the curator aquarum, Stuttgart 2004. Od starije literature ističemo Prolegomena u Polenijevu izdanju (Poleni 1722).

Pomnije je istraživanje njegova spisa zaživjelo u posljednjih dvadesetak godina, a prije toga uglavnom se raspravljalo i pisalo o Strategemati. Spis De aquaeductu urbis Romae (De aqu.) daje pregled rimskih akvedukata: njihov postanak i razvoj, detaljne opise trasa akvedukata i distribucijske mreže u Rimu, količine crpene $\mathrm{i}$ isporučene vode, vrste cijevi i mjerne jedinice te pravnu i zakonsku podlogu na kojoj počiva dobro gospodarenje crpnjom i opskrbom vode. De aqu. se obično klasificira kao tehnički, stručni tekst, no još uvijek nema potpunog konsenzusa među znanstvenicima - ima mišljenja da se radi o govoru-izvješću održanom u senatu ili pak o političkom pamfletu (Blackman-Hodge 2001: 137-150).

Treba ipak imati na umu, naročito ako se u obzir uzimaju i drugi pisci tehničkih tekstova, da nam ništa slično spisu De aqu. nije ostalo očuvano. Tematika se rimske vodocrpnje javlja još kod Vitruvija i Plinija te par usputnih crtica kod drugih autora, no jedino joj je Frontin posvetio zaseban tekst. U okviru specijalnih, odnosno tehničkih registara, Frontinov su leksik istraživali Callebat (1974: 213-329) i Hernández González (1983: 253-265, 1985: passim), dok se Espinilla Buisán (1998: 642-654) dotakla nekih njegovih posebnosti radi dokazivanja jezičnih pojava na širem planu.

Termini su u ovom radu grupirani jednim dijelom po sličnostima ili zajedničkim svojstvima (pogl. 2-9), a jednim dijelom gramatički (pogl. 10-13: hapaksi, sufiksalna tvorba, sinonimija...). Budući da je ovaj rad preopširan u zadanim okvirima po pitanju kvantitete, no da ne bi bio na neki način oslabljen nedostatkom kazala, upućujemo ovdje na dva izvrsna rada-kazala Frontinova leksika, s preglednom ubikacijom, kvantifikacijom i frekvencijom: G. Bendz, Index verborum Frontinianus, Lund-Leipzig 1939. te J. Costas Rodriguez, Frontini index, Hildesheim 1985.

Općenito o tematici rimskih akvedukata s povijesnog, arheološkog i inženjerskog aspekta: B. Ilakovac, Rimski akvedukti na području sjeverne Dalmacije, Zagreb 1982., P. J. Archer, Guide to the Aqueducts of Ancient Rome, Wauconda 1995., R. A. Staccioli, Acquedotti, fontane e terme di Roma antica, Rim 2002.

Izvorni je tekst De aqu. lako dostupan i na mrežnim stranicama, npr. http://www. thelatinlibrary.com/frontinus/aqua1.shtml; http://penelope.uchicago.edu/Thayer/E/Roman/ Texts/Frontinus/De_Aquis/), kao i engleski prijevodi (npr. http://www.uvm.edu/ rrodgers/ intro.html). U ovom se radu koristilo Teubnerovim izdanjem (Kunderewicz 1998).

\section{Početak akvedukta - izvorišta i izgradnja}

Izvorište se akvedukta navodi s concipitur, uz koji stoji subjekt (V 4; VI 5; VII 6; VIII 2; X 5; XIV 1), osim jednom (XI 3), kad nije naveden; osim kao "počinje", može se shvatiti i kao "izvire"; Usp. conceptio (LXVI 6; LXVII 7; LXXI 1; LXXII 6; LXXIII 4) u značenju "količina vode na početku-izvoru akvedukta". ${ }^{1}$ Mjesto gdje se izvršila kaptacija, odnosno izgradio početak

V. Del Chicca 2004: XX. Dodaje ona k tomu i glagole excipio i colligo. Excipitur, međutim, na mjestu gdje bi po Frontinovu uzusu očekivano bilo concipitur, stoji samo jednom (XVI 1: excipitur ex flumine), eventualno dvaput (XIX 1: ex his sex ... contectis piscinis excipiuntur). Ima još četiri primjera gdje dolazi excipio, no za razliku od prethodnih dvaju primjera, gdje uza nj dolazi ablativ (mjesto), u njima je triput izražen cilj (in + akuz.): XXVII 3: in castellum excipiuntur; LXVII 5: in arcus excipitur; XCIII 3: lacuum altitudine in quos excipitur; a jednom on stoji u relativnoj rečenici uz apsolutni komparativ, XCII ... pluribus ex causis, quo inferior excipitur, minus salubris ... exiret. Čini se da ima sličnosti, tj. sinonimije, između excipitur/excipiuntur i recipitur/recipiuntur. V. XIX 3: in eosdem arcus recipiuntur; XX 1: in altiores arcus recipiuntur; LXVII 6: in arcus recipitur; id. 7: in arcus recipiuntur; LXIX 2: in piscinam recipitur. 
akvedukta, naziva se caput, bilo da se radi o kaptaciji izvirućih voda, bilo iz rijeke, bilo iz jezera (V 5; VII 8; IX 3; XVIII 4; LXIV 4; LXV 2, 7; LXVI 2, 5, 7; LXVII 2, 6, 8, 9; LXVIII 3; LXIX 2; LXX 2; LXXII 2, 4, 5; LXXIII 2; LXXV 1; LXXXIX 4). Izgradnja i uvođenje akvedukta u grad naznačuje se složenicama od ducere (perducere, adducere, inducere), dok se simpleks može naći u značenju "trasiranja voda-cijevi", ili derivacije vode (aquam ducere). Značenje se simpleksa može gotovo u potpunosti podrediti izrazu aquam ducere, što u konačnici znači jednostavno crpnju, opskrbu, dotok vode. Također, vidi se da u primjerima gdje stoji ducere, uvijek je tom glagolu objekt "aqua", bilo da je izričito naveden, ili se da domisliti: III 2: quod ius ducendarum tuendarumque sit earum; (tako i na sljedećim mjestima: XXXV; LXXXVII 3; LXXXVIII 2; XCI 3; XCIV 1, 5; CIII 2; CVI 3; CIX 6; CXIII 2).

Perducere je većinom u značenju koje obuhvaća neki građevinski zahvat nad objektom -akveduktom ili njegovim nekim dijelom. Samo u jednom slučaju glagolu perducere nije objekt aqua (kao i prije, bilo izričito navedena, ili se dade domisliti): CII 1: Cum perduxerimus rem ad initium curatorum, non est alienum subiungere qui post Messalam huic officio ad nos usque praefuerint.; dok u svim ostalima jest: III 1: quoto post urbem conditam anno perducta sit (sc. aqua); (kao i: VI 1, 3, 4; VII 2, 3, 5; VIII 2; X 1; XI 1; XII 1; XIII 3; XVIII 4, 7; LXXVI 5, 6; LXXXVII 4; CIV 4; CXVI 4).

Inducere dolazi dvaput u značenju kao i perducere (V 1; CV 2), uz jedan slučaj gdje nije tako: XXV 1: Postea modulus ... inductus.

Adducere se javlja jednom, u jednakom značenju kao i perducere (VIII 1).

Radi li se o grananju ili račvanju dotoka vode, glagol je diducere: XX 2: in usum urbis fistulis (sc. aquae) diducuntur; XXI 3: per urbem (sc. aqua) diducitur.

Stoji on također u jednom primjeru, a da nije aqua u blizini, nego uz familia: CXVII 1: familia in aliquot species diducitur; 4: in privata opera (sc. familias) diduci.

Deducere se nalazi dvaput. Jednom u poziciji kao i ducere: CV 1: aquam in usus privatos deducere; a jednom kao i perducere: X 1: post annum tertium decimum quam luliam deduxerat.

Za određenje se trase koriste derigo i derectura (vrlo rijedak termin, potvrđen još kod Vitruvija, VII 3, 5, no s drugim značenjem)2. Npr. XVIII 4: sed veteres humiliore derectura perduxerunt (sc. aquam), ... (također XX 4; CXXIV 4; CXXVI 4).

\section{Vodovi}

Što se vodova tiče, termini su specus, canalis, forma, ductus, alveus, ramus, derivationes, adquisitiones.

Specus znači glavni vod, bilo čitavog akvedukta (npr. XV 2: interposita est piscina limaria, ubi inter amnem et specum consisteret et liquaretur aqua; jednako tako i: XVII 3; XCI 3; CXXIV 4), bilo jednog njegova dijela (koji pak, ipak čini određenu zasebnu jedinicu - cjelinu): XXI 2: partem dat in specum qui vocatur Octavianus.

Zanimljivo je da se kod Frontina nalazi pretežno u muškom rodu (gdje je sa sigurnošću moguće utvrditi), a tek jednom u ženskom rodu. Muški je rod češći, i to je klasični oblik, dok je ženski pred- i postklasični (LD 2002: 1739).

Canalis znači općenito cijev, kanal, neovisno o tome je li otvorenog ili zatvorenog tipa, a posebice cijev ili kanal za vodu, vod. Nalazi se još i kod Katona, Varona, Vergilija, Cezara, Livija, Svetonija, Vitruvija, Plinija (LD 2002: 276; TLL III 224, 11). Npr. XIX 3: modum accipit ac proprio canali et nomine venit (također: LXXVII 5; CXXIV 3). Čini se da kod Frontina ipak znači zatvoreni tip voda, a nije jasno je li mogao biti načinjen od još kojeg materijala, osim olova.

Del Chicca 2004: XX: “Per la determinazione del percorso è usato derigo, e derectura (...) per il 'tracciato' dei ductus". V. TLL V.1, 1230, 11: tt. architecturae. 
Forma se u De aqu. javlja triput, i to u trima različitim značenjima (v. TLL VI.1, 1110, 71-1113, 22). U XVII 3: formas quoque ductuum facere curavimus; ima značenje "planovi, karte"; u CXXVI 4: vicinales vias agrestesque per ipsas formas derigunt; znači sâm akvedukt (LD 2002: 768); dok je zanimljiv primjer LXXV 3: plerique possessorum ... formas rivorum perforant; gdje bi značenje trebalo biti "vodovi, cijevi" (LD 2002: 768). Iz tog se značenja razvilo netom navedeno iz prethodnog primjera. ${ }^{3}$

Pitanje je je li možda moguće tumačenje da je izraz forma rivorum zapravo primjer gdje se upotrebljava apstraktan izraz mjesto konkretnoga, pa tako znači ili formosos rivos, ili jednostavno samo rivos. Formosus se odnosi na vidljivo, ali ne samo na živo, već i na predmete (LD 2002: 769; TLL VI.1, 1110, 71-1113, 22). Čini se da to ne bi bilo neuobičajeno za Frontina. K tome, kontekst donosi svojevrsnu kontrarnost između impozantnih vodova i cijevi te negativnih postupaka (derigere, perforare) pojedinaca, koji pak nimalo ne imponiraju svojim ponašanjem, tako da se može razmatrati takvo "pregnantno" značenje u tom apstraktnom izrazu.

Alveus u De aqu. dolazi kao termin iz, čini se, jezika struke, a znači unutrašnji dio voda. U tom ga se značenju nalazi samo kod Frontina (LD 2002: 100; TLL I 1791, 15). Moguće je da je došao analogijom prema značenju "korito rijeke" pa sukladno tomu i "korito" voda (CXXI 4; CXXII 3; CXXIV 3).

Ramus u De aqu. znači ili ogranak akvedukta (npr. V 6: iungitur ei ad Spem veterem ... ramus Augustae ...; također i LXV 3), ili pak protuzakonito postavljene cijevi (kojih je toliko da čine čak i ogranke), npr. CXV 4: aliquantum plumbi sublatis eiusmodi ramis redactum est.

Derivatio u De aqu. dolazi jednom. ${ }^{4}$ Čini se u jednakom značenju kao i ramus, no s jasno navedenim negativnim kontekstom: derivatio = ramus "inlicitus". IX 8: Iulia autem revocatis derivationibus, per quas subripiebatur, modum suum quamvis notabili siccitate servavit.

Adquisitio dolazi u značenju dodatne, nove količine vode (do čega je došlo Frontinovim radom i poduzetim mjerama) ${ }^{5}$, npr. LXXII 7: quod si qui forte me adquisitionum mensuris blandiri putant, admonendi sunt; (jednako tako LXXIII 3; LXXVII 1). No, može doći i u značenju odvojka za dodatnu, pomoćnu opskrbu vodom, npr. X 6: adiuvatur et compluribus aliis adquisitionibus.; 8: adquisitionum ductus rivi subterranei efficiunt... $\mathrm{U}$ dvama je primjerima riječ o višestruko kaptiranom početku-izvoru akvedukta (LXIX 2: ad caput... quoniam ex pluribus adquisitionibus constat; tako i LXX 2).

Zanimljiv je i grecizam euripus (LXXXIV 3), koji se u Frontina javlja u specifičnom značenju cjevovoda akvedukta Virgo u neposrednoj blizini Agripinih termi. U tom značenju dolazi još u Ovidija i Seneke (TLL V.2, 1077, 72-81).

\section{Slobodni pad i učinci gravitacije}

Termini vezani uz učinke gravitacije tiču se nivelacije (libramentum, ars librandi, libra: VI 6; XVIII 1, 4; XIX 5; XXIII 1; XXXVI 2; LXV 7; LXXIII 6; XCI 1; CXXIV 3), odnosno visinske razlike, tlaka i protočnosti vodova (altitudo, velocitas, pressura, segnitia ${ }^{6}$ ductus: III 2; XIII 5; XVIII 3; XVIII 3, 7; XXXV; LXV 3; LXXIII 6; XCIII 3).

LD 2002: 768: formas rivorum perforare, i.e. the conduits, pipes, Front. Aquaed. 75: aquaeductus, Dig. 7, 1, 27. - Hence, b. Transf., the aqueduct itself, Front. Aquaed. 126.

$4 \quad$ Iscrpnije o značenju v. TLL V.1, 634, 64.

$5 \quad$ V. Espinilla Buisán 1998: 646: “... Frontin le spécialise (sc. termin adquisitio) dans le vocabulaire de l’hydrologie avec le sense concret d' 'eaux de complément', c'est-à-dire de l'accroissement produit sur le débit d'une eau." U svom radu nije, međutim, dala nikakve naznake o mogućnosti i drugih značenja tog termina.

6 V. De aqu. XXXVI 2: ... (sc. calix) ad latus praetereuntis aquae conversus et supinus, segniter et exiguum sumit. Segnitia dolazi jednom, no ne u "stručnom izrazu", $\mathrm{Cl}$ 2: ... tamen esse curatorum videntur desisse inertia ac segnitia non agentium officium. 


\section{Podzemni i nadzemni dijelovi akvedukta}

Što se tiče vodovodne gradnje, podzemni su dijelovi nazvani rivi subterranei (subterranea), npr. III 1; V 5, 8; VI 6; VII 8; X 7, 8; XIV 4; XV 6; CXXI 3. Pridjev se pak subterraneus, osim uz rivus, nalazi još i uz opus (misli se na izgradnju akvedukta pod zemljom, pa opus subterraneum ima šire značenje) XII 1: ... aliam aquam eiusdem bonitatis o p e re subter ra n e o perduxit usque ad Marciae rivum, ...; i uz circuitus (gdje označava zakrivljenu trasu akvedukta preko nizine) XVIII 5: iam tamen quibusdam locis, ... o misso circuito subter ra ne o vallium brevitatis causa...

Substructio dolazi u značenju podzida (III 1; V 5; VI 6; VIII 8; IX 3; X 7; XIV 4; XV 6; XVIII 5, 6; CXXII 1); za lučne se konstrukcije koriste opus arcuatum (III 1; VIII 8; IX 3; X 7; XI 4; XIV 4; XV 6; LXXVI 6), arcuatura (V 5; osim kod Frontina - no, ima mjesta sumnji - potvrđeno s drugom grafijom u Itali i Vulgati) (TLL II 473, 67), arcuationes (hapaks; XVIII 5, 6; CXXI 1) (TLL II 473, 62); concamerationes kao bačvasti "svod" za zatvaranje vodova (CXXVI 3)7; tectoria (CXXII 1) za nepropusni sloj unutrašnjih dijelova (latera: CXXII 1; CXXVI 3; CXXVIII 2); inchoatum je privremeni vod prilikom popravaka (CXXIV 3); u značenju se pouzdanosti akvedukata javlja fides (LXIV 3). ${ }^{8}$

Piscina limaria (XV 2) javlja se samo jednom, u ostalim slučajevima jednostavno piscina (pridjev limarius je hapaks) (TLL VII.2, 1401, 45); usp. i conceptacula (XXII 1).

\section{Distribucija i protok vode}

Za isporuku vode i njezinu distribuciju koriste se divido, distribuo, discribo, dispenso, dispensatio, distributio; erogo, erogatio; salio; exeo; servio. Vodospreme se uglavnom nazivaju castellum, javni se vodoskoci zovu lacus, salientes, munera (semantički hapaks) (TLL VIII 1666, 35). Olovne se cijevi nazivaju fistulae; modulus je mjera; atributi su acceptorius (TLL I 283, 73) i erogatorius (TLL V.2, 799, 47) hapaksi. Uređaj za regulaciju protoka vode je calix, za koji se čini da nije potvrđen izvan teksta De aqu. (Del Chicca 2004: XX), no našao se jednom i kod Paulina iz Nole (TLL III 165, 27).

Više je naziva koji se odnose na tok i prekid dotoka vode: fluo, abundo; intermitto, intercipio, interpello, cesso. Tehnički je izraz aqua caduca (TLL III 34, 22) (za razliku od LXXXVIII 3: pereuntes ... aquae, što označava vodu koja se prelijeva i otječe). Gubitci su i kvarovi manationes (rijedak izraz i zabilježen počevši od Frontina) (TLL VIII 251, 5).

\section{Stručno osoblje}

Što se izraza tiče za razne robove-majstore (servi opifices), iz dviju familiae aquarum, silicarii su zabilježeni samo u libri regionum (Curiosum urbis Romae regionum XIIII; Notitia urbis Romae) (Del Chicca 2004., XX), a castellarii su zabilježeni epigrafski (TLL III 254, 78); specifični su za vodoopskrbni sustav circitores $^{9}{\text { i } \text { tectores }^{10}}$ vilici $^{11}$ i libratores (rijetko,

Rijedak izraz, potvrđen još kod Vitr., II 4; V 10; i Plin., XI 10, 10, 22; Dig., XXXII 31.

8 Del Chicca 2004: XX, navodi još i putea kao odihe, odnosno kanale za prozračivanje i lakši pristup vodu. Ta lekcija stoji u njezinu izdanju u paragrafu LXXXIX 4 (p. 76). No, u izdanju je kojim se ovaj rad služi lekcija na tom mjestu plutea, a jedini je primjer za puteus u IV 1, a značenje je očito "puč" (bunar).

9 V. TLL III 1100, 70. Zabilježeni su još epigrafski, a u tekstovima počevši od Frontina, to jest još kod Ulpijana u tom značenju.

10 Rijetko, potvrđeno još kod Cic., Planc. XXV 62; Varr., RR III 2, 9; Vitr., VII 3; V. LD, 1845.

11 Potvrđeno još kod luv., IV 77, i Lampr., Alex. Sev. 15; V. LD, 1990. 
zabilježeno epigrafski te kod Katona i Plinija ${ }^{12}$ ), te aquarius kao tehnički termin (TLL II $366,29)$.

\section{Kapacitet akvedukta i količina vode}

Što se tiče kapaciteta akvedukata (modus, copia) javljaju se razne riječi iz jezika financija, kao accepta (v. i prvotno značenje erogare, erogatio, adquiro, adquisitio i metaforu u LXIV 3) (Del Chicca 2004: XX). Količina se vode na početku akvedukta naziva i concepta i conceptionis modus - "modus aquae ad caput collectae", dok se adquiro i adquisitio odnose posebice na nove količine javne vode, zahvaljujući Frontinovu radu.

\section{Stručni žargon i cijevi}

Ima termina za koje je izgledno da, ako i ne pripadaju žargonu (npr. punctum (a punctis) malena mjera za tekućinu (LD 2002: 1492); v. i munera i fistulae solutae), onda pripadaju bar stručnom govoru: segnitia ductus i onerare/relevare erogationem. Pod stručnim se govorom ovdje misli na onaj u širem smislu (općenito lingua rerum technicarum), dok se žargonom smatra onaj u užem smislu, tj. govor struke neposredno vezane uz akvedukte.

Ono što bi se moglo izdvojiti kao jezik stručnog žargona, jesu nazivi za cijevi: quinaria, senaria, septenaria, denaria, itd. Pridjev je quinarius uglavnom u uporabi u postaugustovsko vrijeme, a može značiti ili cijev, ili novac - quinarius kao polovica denarija. Navedeno je značenje cijevi kod Frontina i Plinija, dok je u značenju novca u Varona, Plinija, Servija (Verg. G.) i Makrobija (LD 2002: 1513). Kao cijev se ipak još nalazi kod Vitruvija, a kao novac u fragmentima Apuleja i u Voluzija Mecijana. Kao cijev je Plinije navodi triput (ali u istom paragrafu: XXXI 58, 2; 5; 6), dok je, zanimljivo, u Vitruviju samo jednom (VIII 6, 4). U De aqu. se quinaria javlja preko dvjesta puta. Logičnima se nameću stoga pitanja, zašto "peticu" smatrati terminom stručnog žargona, odnosno kako objasniti toliku razliku kod Frontina i Vitruvija (koji također piše o vodi, a po mišljenju je nekih njegovo djelo reprezentativni primjer i skup najboljeg što se može doznati o rimskoj vodoopskrbi iz antičkih tekstova, dok su osnovni principi struke Frontinu bili nepoznati) (Blackman-Hodge 2001: 144).

Naziv quinaria - "petica" (redovito kao supstantivirani pridjev; uz pridjev stoji fistula tek dvaput: XXX 1; XXXI 1), da se usporediti s današnjim terminima iz vodovodnog "žargona". Tako se cijev dijametar je koje "palac", naziva "colerica" (njem. zoll - palac ${ }^{13}$ ). U drugim je slučajevima oznaka mjere ujedno i sinonim za cijev određene veličine pa tako: "tri osmine, pol cola, tri četvrt, pet četvrtina, šest četvrtina, dva cola”. Uz te, tu su još i mjere u milimetrima (za kanalizacijske cijevi, ili novije plastične za vodu, obično većih profila), koje se navode ili samo brojem ili brojem uz prethodno naveden "fi" (oznaka ø): 30, 40, 50, 75, 80, 100 (poznata u vodoinstalaterskom žargonu kao "stodesetka"), 125, itd. Osnovno je i temeljno za svakog vodoinstalatera to da bezrezervno i besprijekorno poznaje problematiku mjera cijevi i njihovu uporabu.

\section{Hapaksi}

Osim stručnih i tehničkih termina koje nam Frontinov leksik pruža, posebno je njegova vrijednost u hapaksima, koji su već spomenuti. Ne čini se, međutim, zgorega nekako in rekapitulirati i pokušati reći nešto više o njima, koliko se može.

12 V. TLL VII.2, 1348, 66.

13 Ne radi se međutim o colu koji je izjednačen s anglosaskim inčem $(=2,54 \mathrm{~cm})$, već o staroj njemačkoj stolarskoj mjeri koja iznosi cca. $2,8 \mathrm{~cm}$. 
Hapaksi se u De aqu. mogu podijeliti na leksičke i semantičke. Semantički su hapaks munera (ukrasni vodoskoci) (III 2; XXIII 1; LXXVII 3; LXXIX 2; LXXX 2; LXXXIII 2; LXXXIV 2; LXXXVI 3; LXXXVIII 1; XCVIII 1; CXVII 3; CXVIII 2). Tu bi se možda moglo još pribrojiti i calix - svojevrsni "vodomjer" (XXXVI 1, 3; CV 4, 5; CXII 2, 3, 5, 6; CXII 1, 3; CXXIX 11) ako se ne prida posebna vrijednost tomu da se javlja još kod Paulina iz Nole; te castra (ako se prihvati značenje velike vodospreme) (LXXVIII 3; LXXIX 2; LXXX 2; LXXXI 2; LXXXII 2; LXXXIII 2; LXXXVI 3).

Ostali su hapaksi: arcuatio, arcuatura, limarius (XV 2), acceptorius (XX 5), erogatorius (XX 5). Mogu se k tomu pribrojiti i manatio (LXV 5; CX 1; CXXII 1), koji se javlja još kod Marcela Empirika i u Itali, te adquisitio (semantički hapaks) koja se u konkretnom značenju javlja samo kod Frontina (X 5, 8; LXXIX 2; LXXVII 1), dok u apstraktnom još u Dig. i Tert. (LD 2002: 24). Iz toga se vidi da je u trima slučajevima hapaks tvoren sufiksom -arius/-orius i radi se o pridjevima, a kad su posrijedi imenice, također triput sufiksom -tio, a tek jednom sufiksom -tura. Tim se sufiksima u tekstu De aqu. pozabavila Espinilla Buisánova. U svom je radu ponajprije htjela potvrditi Fruytovu tezu o isključivo sintaktičkom kriteriju pri opisu sufiksalne funkcije u latinskom, odnosno ukazati na to da supstantivi na -tio, -tura i -tus, iako apstraktne tvorbe, pokazuju tendenciju ka konkretnom značenju (Espinilla Buisán 1998: 643-646). To je i njezin odgovor na Benvenisteovu tezu o semantičkoj razlici među tim trima sufiksima: -tus "prikladnost ili sposobnost subjekta, način obavljanja radnje", -tio "činjenica objektivno obavljene radnje", -tura "primjena sposobnosti". U radu je dan kvantitativan pregled riječi s navedenim sufiksima, no tako da se više pažnje posvetilo sufiksima -tio i-tura, budući da riječi tvorene sufiksom -tus pokazuju najmanji stupanj tehnifikacije, a većina ih je iz pravnog jezika (arbitratus, consensus, permissus, iussus, itd.). Tako Espinilla Buisánova izdvaja osam neologizama, s time da po strani ostavlja "četiri inovacije sa sufiksom -arius / -orius (castellarius, silicarius, acceptorius, erogatorius)". Ostali su arcuatura, adquisitio, manatio, arcuatio. Buisánova nadalje tvrdi da Frontin preferira uporabu supstantiva na -tio u konkretnom značenju mjesto konkretnog supstantiva (adquisitio : sedam primjera, šest u pluralu, dok tek jednom: IX 2: adquisitae aquae ab inventore nomen luliae datum est; manatio: tri primjera, tek jednom LXV 5: id, quod ex ea (aqua Appia) manat). Za ta dva termina piše da su hapaksi, bez dodatnih komentara o tome javljaju li se gdje drugdje. Što se tiče termina arcuatio, navodi da je to dubleta s riječju arcuatura, te ukazuje na to da se radi o primjeru gdje dolazi do apsolutne sinonimije, onako kako ju je opsao Fruyt. U slučaju lučnih konstrukcija Buisánova ukazuje ne samo na dubletu, već i na tripletu: opus arcuatum / arcuatura / arcuatio, no i upozorava da se ipak Frontin priklanja konkretnom izrazu (opus arcuatum - 11 primjera) prilikom korištenja tih sinonima, a kada se pak radi o determinaciji dijela akvedukta, tada Frontin koristi arcus (Espinilla Buisán 1998: 648). Zaključuje tako da su krajem I. st. po Kr. kod Frontina riječi na -tio i -tura potpuno prikladne za izricanje konkretnog i kolektivnog, postavljajući pitanje metodološkog pristupa koji je imao Benveniste u svom radu Noms d'agent et d'action en indo-européen (Espinilla Buisán 1998: 650). 
Evo i tabele, kako je daje Buisánova, o frekvenciji riječi sa spomenutim sufiksima (Espinilla Buisán 1998: 654).

\begin{tabular}{|l|c|c|c|}
\hline \multicolumn{1}{|c|}{ riječi } & -tio & -tus & -tura \\
\hline stari latinitet & 185 & 164 & 29 \\
\hline de aqu. & 50 & 23 & 9 \\
\hline de aqu. (veteres) & 10 & 14 & 4 \\
\hline de aqu. (\% veteres) & $20 \%$ & $60,8 \%$ & $44,4 \%$ \\
\hline de aqu. (neologizmi) & 3 & - & 1 \\
\hline $\begin{array}{l}\text { nove riječi u postkl. latinitetu } \\
\text { (prema Paukeru) }\end{array}$ & 339 & 162 & 51 \\
\hline
\end{tabular}

\section{Sinonimija u nazivima za lukove: arcus, opus arcuatum, arcuatio,}

\section{arcuatura}

No, ima u tetrameriji tih termina jedan zanimljiv moment, koji se ne može tako olako zanemariti. Evo o čemu se, naime, radi.

Arcus, koji Frontin rabi u, kako je primijetila Buisánova, determinativnoj funkciji, dolaze dakle (od deset primjera ${ }^{14}$ ) uvijek u pluralu, ili u nominativu (tri primjera, XV 7: hi sunt arcus altissimi; XX 2: finiuntur arcus earum (Anionis novi et Claudiae); XXII 2: arcus Virginis initium habent), ili u akuzativu (XIX 3: in eosdem arcus recipiuntur; XX 1: in altiores arcus recipiuntur; id. 3: in arcus qui vocantur Neroniani; XXI 1: inter arcus traicit (Anio novus); LXVII 6: (summa) in arcus recipitur; id. 7: (quinariae) ex piscina in arcus recipiuntur; LXXXVII 3: sola Claudia per arcus Neronianos ducebatur).

Opus arcuatum dolazi u 11 primjera, no isključivo u abl. sg. (III 1; VII 8 (dvaput); IX 3; X 7; XI 4; XIV 4 (dvaput); XV 6 (dvaput); LXXVI 6).

Arcuatio dolazi u četvorima primjerima, uvijek u abl. pl. (XVIII 5, 6; CXXI 1). Buisánova ipak dopušta da se uzme u obzir moguću koordinaciju u primjerima XVIII 5 i 6 , kao i to da se radi o eventualnoj estetskoj elaboraciji qui combinerait un groupement binaire avec I'homéotéleute (Espinilla Buisán 1998: 649), no odmah iza toga navodi da je rad Luisa Callebata pokazao da formalne i fonetske strukture, povremeno emfatičkog karaktera, ne sudjeluju odveć u dekoraciji Vitruvijeve rečenice (1998: 650). Da se jednako može reći i za tu situaciju s arcuatio u De aqu., nije baš sigurno. Štoviše. Buisánova je odbacila mogućnost kriterija prostorne distribucije koji je predložio Hernández González da bi objasnio tvorbu riječi arcuatio: "dada la cercanía de substructio, nos atrevemos a afirmar que arcuatio es un substantivo en -tio formado por analogia con substructio", navodeći kao protuargument dio V 5: supra terram substructio et arcuatura (Hernández González 1985: 667). Čini se, međutim, da se ipak valja prikloniti Gonzálezovoj tezi. Tome u prilog ide činjenica da se arcuatio uvijek javlja uz substructio (u abl. pl.) i čini spoj koordinacije i homoioteleuta. Protuargument koji daje Buisánova jest, najblaže rečeno, sumnjiv.

Arcuatura se u De aqu. jvlja samo jednom, u spomenutom dijelu V 5. Kunderewicz se u kritičkom aparatu uopće ne osvrće na tu riječ (Kunderewicz 1998: 3). Del Chiccova u

14 Ne ubrajam primjer VII 7: sub <arcu>bus. Tu je lekciju predložio i dao Kunderewicz (p. 6). Grimal je predložio lekciju sub <...>bus, dok u rukopisima CAE (V. Kunderewicz 1998., 6) nailazimo na lakune <...>bus. Oblika arcubus u Frontina ne nalazim. Pojavljuje se takav oblik abl. još kod Remija, M. Manilija, Flavija Kapra, u script. H.A. i Servija. U ovom se slučaju radije priklanjamo Grimalovu rješenju. 
svom izdanju teksta također, a komentari su joj u kritičkom aparatu po pitanju retka u kojem stoji arcuatura jednaki Kunderewiczevima (Del Chicca 2004: 8). Tog se termina ipak dotiče u komentaru, no uzima tu lekciju zdravo za gotovo. ${ }^{15}$ Zanimljivije postaje kad se pogleda u Rodgersovo izdanje, koji isto donosi lekciju supra terram substructio et arcuatura, no u kritičkom aparatu navodi: "arcuatura suspectum: <opus> arcuatum Bücheler (substructione et arcuatione Polenus)" (Rodgers 2004: 67). U komentaru je izrazio svoju duboku sumnju u tu lekciju, pojasnivši mogućnosti. ${ }^{16}$ Polenijeva je lekcija (Poleni 1722: 16): supra terram substructione \& arcuatione, a u komentaru kaže: "[supra terram substructione \& arcuatione proxime ad Portam ] Codices Cassinensis, \& Vrbinas ita habent; supra terram substructio \& arcuatura proximum Portam : editio locundi; substructione \& supra terram opere arcuato proximæ ad portam: sed locus hic haud bene a locundo emendatus fuit; ut conferenti locum ipsum cum verbis Codicum, \& cum similibus locis aliis, liquere profecto poterit" (Poleni 1722: 16, n. 21). Također, ovako je to komentirao Keuchenius u svojim bilješkama uz Polenijevo izdanje teksta: "[supra terram substructione \& arcuatione] (\& supra terram opere arcuato.) Quod arcus nimirum \& fornices habet, non solidam constructionem. Hoc obsevatu dignissimum est, quia nihil magis obvium in Commentario Aquæductuum" (Poleni 1722: 251).

Unatoč tome što je krajnje rijetka i što ju je Frontin ipak mogao upotrijebiti, srž se problema nalazi u tome da je sama lekcija u V 5: arcuatura sumnjiva do te mjere, da ju je najbolje zanemariti. Moguće je tako da je Hernández González ipak bio u pravu, tvrdeći da je termin arcuatio stvoren analogijom prema substructio. $U$ tom se slučaju ne može govoriti o tripleti opus arcuatum / arcuatio / arcuatura (ako ima triplete onda je to opus arcuatum / arcus / arcuatio), niti posljedicama koje bi time uslijedile. Taj bi primjer pokazao da je vrlo vjerojatno arcuatio nastala pod utjecajem substructio, odnosno izbor je pao na sufiks -tio zbog određene "dekoracije" - emfaze, figurativnosti. Dakako, ako nije po srijedi pogreška pisara.

\section{Termini na -arius/-orius}

Govoreći prije o hapaksima, navelo se i tri primjera pridjeva tvorenih sufiksima -arius / -orius (limarius, acceptorius, erogatorius). No, nisu to jedine riječi tvorene tim sufiksima. Osim njih, u De aqu. se još nalaze: praesidiarium, plumbarii, castellarius, silicarius, adiutorium, tectoria te većina naziva za standardne cijevi $^{17}$. Ne zaboravimo i nezaobilazne vodovodare (aquarii). Praesidiarium, adiutorium i tectoria su očito rijetki tehnički stručni termini (LD 2002: 1429, 38, 1845). Također su na svoj način izuzetni i plumbarii, castellarii i silicarii, budući da su također rijetki i tehnički termini (LD 2002: 1388, 297, 1699). Nemoguće je i ne

15 Del Chicca 2004: 157: “-arcuatura: il termine, usato solo in questo passo (v. anche Espinilla Buisán, 647 ss.), di contro ad arcuationes e ad opus arcuatum, più frequenti nel De Aquae ductu, ha scarse attestazioni: compare in Vet. Lat. cod. Mon. exod. 38, 32; 37, 17; cod. Leg. III reg. 7, 9, in CIL VI 31564 riguardante i restauri constantiniani della Virgo (formam aquae Virginis vetustate conlapsam a fontibus renovatam arquaturis eminentibus omnibus dirutam), nelle Notae Tir. 100, 8 arcuatura e nei glossari (Thes. II, 473, 67 ss.)".

16 Rodgers 2004: 148: "In the formulae of these introductory chapters F. regularly uses opus arcuatum, but always in the ablative, and in other contexts his usual word is arcus. The word arcuatura is suspicious: not so much because it is extremly rare, nor yet because F. might have used arcuatio (elsewhere only in plural), but because the single other attestation of the word is in an inscription set up under Constantine (CIL 6.31564=ILS 702, Appendix B, no. 13) - by the curator aquarum et Miniciae, hinting some possible use of F.'s text in the fourth century. The -ura suffix could equally well be the result of scribal misinterpretation of -um (hence Bücheler's <opus> arcuatum) or -io (hence Poleni's arcuatione; for this error cf. 7.5n. collegio ] collega C). ... "

17 Osim cijevi u nazivu se kojih spominje petica u deseticama (vicenum quinum, itd.) i stodvadesetice (centenum vicenum). 
zamijetiti sličnosti među tim "vodovodnim" i vojnim terminima (tako npr. strat.: cornicularius, sagittarius, triarius, mercennarius; Liv. praesidiarii milites. Castellarius i silicarius nalazimo epigrafski, ali kao navedeno zanimanje potpisanog roba-majstora. Sukladno onome što navodi gramatika (LG 1965: 211), sufiks se -arius javlja još u praitalskom - dakle poprilično je star, a primjeri nisu tako brojni. Za sufiks -torius / -sorius gramatika kaže da korespondira grčkom -tnpıos i da se razvio od nomina agentis i sufiksa -yo-s (LG 1965: 213).

\section{Castra / castellum}

Već smo prije spomenuli termine koji se tiču isporuke vode, koja se pak dijelila na vodu za javnu i privatnu potrošnju i u Cezarovo ime. Javna se pak potrošnja dalje dijeli na vodu za castra, javne građevine (opera publica), vodoskoke (salientes), ukrasne vodoskoke (munera), i javne zdence (lacus). Od recentnih izdanja, i Rodgers i Del Chiccova iskazuju svoje sumnje oko značenja termina castra. Tako: "It is not clear what F. means by castra. The numbers alone indicate more than the castra praetoria, which was in F.'s day the barracks for the cohortes urbanae (RE Suppl. 10,1026) as well as for the praetorian guard, and might in any case have recieved its water nomine Caesaris" (Rodgers 2004: 245). Odnosno: "II termine, ... ricorre solo nei capitoli sulla ripartizione trascritti dai registri appositi ... ; Frontino non segnala alcun significato speciale, ... . La suggestione etimologica ha fatto pensare a un'indicazione analoga a quella di castellum, e quindi a conserve d'acqua, cisterne (Bruun 1991, 103, n. 30 e 250 ss.), ma, in mancanza di altri riscontri, preferiamo restare nell'ambito dell'accezione di "caserme, acquartieramenti"; ... " (Del Chicca 2004: 337).

Problemu je pokušao nedavno doskočiti A. Wilson svojim radom "The castra of Frontinus", temeljenim na Del Chiccovoj spomenutoj etimološkoj sugestiji, potpomognutoj arheološkim aspektom. Sukus se tog rada može vidjeti u ovim dvjema njegovim rečenicama: “... Frontinus, and other writers, such as Vitruvius, use the term castellum, which originally meant a small fort, in the sense of a water distribution tank (sometimes castellum divisorium). Castellum is of course the diminutive of castrum or castra, and one could argue that Frontinus should be using castra to mean some larger entity than a distribution castellum - for which the obvious candidate would be a large reservoir or storage cistern (as distinct from a settling tank, which is a piscina limaria)" (Wilson 2007: 440).

Wilson se dijelom oslanja i na tezu prije rečenog Bruuna, koji je sugerirao da se pod castra podrazumijeva: “... some sort of fountain, cistern or castellum ... it cannot be regarded as implausible that another category of "public water posts" (Bruun 1991: 253). Evans je takvu mogućnost odbacio iz prilično teško shvatljive logike: "Even more problematic is the use of the term to indicate a 'local cistern', if castra were supplied through castella: we would expect the diminutive form to indicate the smaller reservoir or tank, not the larger one within distribution net" (Evans 1994: 10-11, n. 44). Wilson je u svom radu pokazao da castella ne moraju nužno biti velike zapremine, već su arheološki potvrđeni primjeri zapremina od nekoliko kubičnih metara. S druge pak strane, tumači on da su akumulacijski spremnici (castra) mogli biti i zapremine koja je mogla dosezati nekoliko stotina tisuća kubičnih metara vode.

Wilson potom izražava sumnju u to da se vojni termin castellum mogao koristiti za označavanje vodospreme, ukoliko nije postojao termin za vodospremu kao castra, budući da je uporaba deminutiva u tom slučaju nelogična: "There is no other readily understandable reason to call a distribution tank a castellum; it does not look or act in any way like a fort" (Wilson 2007: 440). On potom postavlja pitanje, zašto se termin castra rabi u značenju vodospreme, a kao odgovor, nudi dvije mogućnosti. Prva je da je to možda zbog masivnosti 
vodospreme, a kao drugu navodi moguće paralele između značenja akumulacije vode i smještaja vojnika: “... perhaps, especially, the use of castra for an overnight marching camp suggested a metaphorical transference to the overnight storage function of a reservoir" (Wilson 2007: 440).

Nudi potom arheološke dokaze da bi potvrdio svoju tezu da su se takve vodospreme punile noću, kad je bila manja potreba za vodom te se potom ona koristila preko dana za potrebe puka, a time je bila osigurana dovoljna količina za javne građevine da tijekom dana ne dođe do nestašice. Na kraju zaključuje: "In the present state of our knowledge, a specialised use of the word castra to mean reservoir cisterns makes at least as much sense as trying to find enough separate barracks or 'camps' for military or other associations to make up Frontinus' total of 18" (Wilson 2007: 442).

Valja ipak ovdje uzeti još neke stvari u obzir. Prvo, ne može se sa sigurnošću uzeti u obzir točan broj castra. ${ }^{18}$ Drugo, a kako je dobro uočila i Del Chiccova, castra se javlja jedino u navedenoj particiji distribucije vode, u paragrafima LXXVIII-LXXXVI, a prema njezinim riječima, radi se o prijepisu iz Frontinu dostupnih spisa koji su sadržavali te podatke. Da se radi o prijepisu, može se vidjeti iz LXXXVII 1: Haec copia aquarum ad Nervam imperatorem usque conputata ad hunc modum discribebatur. lako Frontin nije jasno napisao da je podatke prepisao, logičnim se to nameće, jedino ostaje pitanje izvora: radi li se o Agripinim komentarima, ili podatcima iz nešto potonjih vremena ${ }^{19}$. U ostatku teksta nikad ne stoji castra, već uvijek castellum. Sukladno bi se tome dalo postaviti pitanje zašto je Frontin ostavio taj termin, prepisujući podatke, ako je on bio problematičan po značenju. Može se zaključiti da je Frontinu taj termin bio jasan i da nije bilo potrebe mijenjati ga u, npr. castellum. ${ }^{20}$ Treće, no nikako manje važno, jest značenje termina castra (castrum) gledano etimološki. Ernout-Meilletov rječnik kaže ovako: "castrum - retranchement, lieu fortifié. ... Il semble avoir désigné d'abord une propriété gardée ou retranchée. ... Le sens ancien est peut-être 'separation, ce qui sert à séparer' et il y aurait parenté avec castro, castrare. ... castellum: $1^{\circ}$ forteresse, camp fortifié; $2^{\circ}$ château d'eau" (DELL 1951: 185). Posebno je zanimljivo kako se u istom rječniku tumači glagol castrare: “... dénominatif de *kastro-m ce qui sert à couper" (DELL 1951: 185). Iz Waldeova pak rječnika valja izdvojiti ovo: "castrum - mit Wall und Graben umgebenes Lager, castellum - kleineres Lager; Befestigung; auch Sammelbecken bei Wasserleitungen (Wasserschloß). ... abgeschnittener Lagerraum oder locus ad segregandum instructus (Thes.)” (LEW 1910: 139). Nije zgorega dodati i ono što kaže Pokorny, govoreći o prajezičnom korijenu *kes-: "to cut, schneiden... castrum encampement, as abgeschnittenes Stück Land. ... *kastrom - schneidewerkzeug" (Pokorny 2007: 1717).

Gledano, dakle, s aspekta prvotnog značenja, lako je moguće da je Frontin termin castra upotrijebio kao specijalni, tehnički termin, u značenju velike rezervne vodospreme. Sumnje, ipak, i dalje ostaju.

\section{Zaključak}

Analizirani tekst pokazuje zamjetan broj stručnih termina, koji mogu pripadati općenito tehničkom govoru u širem smislu, odnosno stručnom žargonu. Odnose se na građevinske

18 V. kritički aparat, Kunderewicz 1998: 35: duo<devig>inti <qui>nariae? Krohn ducentinariae C ducentenarie AE.

19 Možda iz Klaudijeva vremena, kad su u pogon pušteni akvedukti Klaudija i Novi Anion?

20 Moglo bi se pretpostaviti da mu taj termin možda i nije bio jasan pa ga je, prepisujući, ostavio u izvornom obliku. No, ta mi se mogućnost ne čini odveć logičnom: Frontin očito dobro poznaje problematiku akvedukata, unatoč mogućim opservacijama koje bacaju sumnju na to. 
radove na akveduktima (kaptacija, trasiranje, popravci i sl.), na dijelove akvedukata (cjevovodi, nosive konstrukcije, spremnici i dr.), na isporuku vode, njezin tok i prekid dotoka, na razne stručne službe i kadrove potrebne za gradnju i održavanja, na kapacitete akvedukata. Ima termina i iz jezika prava i financija, što je razumljivo, budući da su te grane bile izravno vezane za vodoopskrbu. Posebna je vrijednost leksika zbog hapaksa na koje se nailazi, odnosno riječi koje su inače rijetke ili slabo zastupljene u drugih autora, a jednako tako i zbog termina koji se s većom ili manjom sigurnošću mogu ubrojiti u žargon struke. Od toga pak daleko čestotnošću prednjači petica, odnosno mjere i profili cijevi općenito. Vulgarizmi koji se javljaju mogli bi biti oznaka tehničkog jezika, jer su takvi tekstovi obično pisani za niži sloj stanovništva, a ne iznenađuju jer je vulgus bio uključen u gradnju akvedukata. Ne može se, međutim, isključiti mogućnost da je time Frontinov tekst bio dostupan i širem sloju stanovništva-čitatelja. Strukovna su djela redovito puna terminologije koja nije ušla u registre "visoke" literature, što ne znači da su bila namijenjena i nestručnjacima. No, možda bi upravo Frontinov primjer mogao biti iznimka, uzimajući npr. u obzir tezu da se radi o svojevrsnom govoru ili izvješću u senatu, ili čak političkom pamfletu.

\section{POPIS LITERATURE}

\section{BLACKMAN - HODGE 2001}

Deane R. Blackman - A. Trevor Hodge, Frontinus' Legacy: Essays on Frontinus' "De aquis urbis Romae", Ann Arbor 2001.

\section{BRUNN 1991}

Christer Brunn, The Water Supply of Ancient Rome: A Study in Roman Imperial Administration, Helsinki 1991.

\section{CALLEBAT 1974}

Louis Callebat, "Le vocabulaire specialize", Revue de philologie de litterature et d'histoire anciennes 48, 1974., 213-329.

\section{CALLEBAT 1990}

Louis Callebat, "Le vocabulaire de I'hydrologie", Voces 1, 1990., 9-22.

\section{DEL CHICCA 2004}

Fanny Del Chicca, Frontino. De Aquae ductu urbis Romae, Rim 2004.

\section{DELL 1951}

Alfred Ernout - Antoine Meillet, Dictionnaire etymologique de la langue latine, Pariz ${ }^{3} 1951$.

\section{ESPINILLA BUISÁN 1998}

Empar Espinilla Buisán, "Les mots en -tio, -tura, -tus dans la prose technique de Frontin: De Aquaeductu urbis Romae", u: Latin vulgaire-la- tin tardif IV, Actes Coll. (Caen, 2.-5. rujna 1994.), (ur. Louis Callebat), Hildesheim - Zürich - New York 1998., 643-654.

\section{EVANS 1994}

Harry B. Evans, Water Distribution in Ancient Rome: The Evidence of Frontinus, Ann Arbor 1994.

\section{HERNÁNDEZ GONZÁLEZ 1983}

Fremiot Hernández González, "Frontino y el léxico de las aguas", Tabona, 4, 1983., 253-265

\section{HERNÁNDEZ GONZÁLEZ 1985}

Fremiot Hernández González, El vocabulario técnico de la hidráulica en Vitruvio, Plinio, Frontino, Faventino y Palladio, diss. ined., Madrid 1985.

\section{KUNDEREWICZ 1998}

Cezary Kunderewicz, Sex. Iulii Frontini de aquaeductu urbis Romae, Leipzig 1998.

\section{LD 2002}

Charlton Lewis - Charles Short, A Latin Dictionary, Oxford 2002.

\section{LEW 1910}

Alois Walde, Lateinisches etymologisches Wörterbuch, Heidelberg ${ }^{2} 1910$.

\section{LG 1965}

M. Leumann - J. Hoffmann - A. Szantyr, Lateinische Grammatik, München ${ }^{6} 1963-65$. 


\section{POKORNY 2007}

Julius Pokorny, Proto-Indo-European Etymological dictionary, A Revised Edition of Julius Pokorny's Indogermanisches Etymologisches Wörterbuch, G. Starostin - A. Lubotsky (ur.), Indo-European Language Association 2007., http://dnghn.org

\section{POLENI 1722}

Giovanni Poleni, Sex. Iulii Frontini de aquaeductibus urbis Romae commentaries, Padova 1722.

\section{RODGERS 2004}

Robert Rodgers, Frontinus, De Aquaeductu Urbis Romae, Cambridge 2004.

TLL

Thesaurus linguae latinae

\section{WILSON 2007}

Andrew Wilson, "The castra of Frontinus", u: Res bene gestae. Ricerche di storia urbana su Roma antica in onore di Eva Margareta Steinby (Lexicon Topographicum Urbis Romae, Suppl. IV), (ur. A. Leone et al.), Rim 2007., 439-444.

\section{SAŽETAK}

Rad izlaže rezultate iscrpne analize tehničkog leksika u djelu $O$ rimskom vodovodu autora Seksta Julija Frontina, dajući tako prilog proučavanju i boljem poznavanju klasičnog latinskog tehničkog vokabulara. Osvrće se na dosadašnja istraživanja tematike i daje neke vlastite pretpostavke. Ukazuje se na zamjetan broj stručnih termina, od onih općih tehničkih do onih koji pripadaju žargonu struke. Termini se tiču gradnje i dijelova akvedukata, distribucije vode, učinaka gravitacije, osoblja, kapaciteta akvedukata te količine vode. Ukazuje se i na povezanost stručnih termina s vulgarnim latinitetom i nude moguća rješenja na pitanja koja se postavljaju.

\section{RIASSUNTO}

\section{Termini tecnici presenti nel trattato Gli acquedotti di Roma}

La ricerca espone i risultati di un'analisi esauriente del lessico tecnico presente nell'opera Gli acquedotti di Roma di Sesto Giulio Frontino, contribuendo in questo modo allo studio ma anche ad una migliore conoscenza del vocabolario tecnico del latino classico. Lo studio tiene conto di ricerche già esistenti sull'argomento ma formula anche ipotesi proprie, indicando un numero considerevole di termini tecnici, da quelli più generici a quelli più specifici, propri del gergo professionale. I termini presi in considerazione sono legati alle tecniche di costruzione, alle varie parti dell'acquedotto, alla distribuzione dell'acqua, all'effetto di gravità, agli addetti e alla capienza dell'acquedotto. Inoltre, è stata determinata una connessione tra i termini tecnici ed il latino volgare proponendo così alcune possibili risposte alle domande prefissate.

Parole chiave: Frontino, de aquaeductu urbis Romae, vocabolario tecnico, terminologia 
